\title{
Accreditation and the Role of the Academic Library in Undergraduate Programs: A Case Study of Fountain University, Osogbo.
}

\author{
Bello Mujidat Adeola \\ Fountain University, Osogbo, Osun State, Nigeria
}

\begin{abstract}
This paper examines the process of accreditation exercise at Fountain University, indicating the role of library in the exercise, in compliance with the National Universities Commission's definition of accreditation. Emphasis was on the library holdings, quantity and quality of materials and their currency. The accreditation exercise indicates that the institution maintains clearly specified educational objectives that are consistent with its mission and appropriate to the degrees it offers. Based upon reasoned judgment, the process stimulates evaluation and improvement, while providing a means of continuing accountability to the public. This study seeks to provide an insight into the accreditation exercise at fountain university, Osogbo, with a view to sharing experiences of the library as the integral part of the institution. The paper thus concluded that the statement of Fountain University accreditation status with the NUC is also an affirmation that the institution is persistently committed to the Commission's principles and philosophy of accreditation.

Keywords: Accreditation, Academic library, National Universities Commission, Fountain University.
\end{abstract}

\section{Introduction}

Accreditation is a process of self-study and external quality review used in higher education to scrutinize an institution and/or its programs for quality standards and need for quality improvement. (Corazon, 2002). The process is designed to determine whether or not an institution has met or exceeded the published standards (set by an external body such as a government, national quality assurance agency, or a professional association) for accreditation, and whether it is achieving its mission and stated objectives. The process usually includes a self evaluation, peer review and a site visit.

Accreditation standards and guidelines in Nigeria educational system is aimed at strengthening programs for quality assurance and quality improvement. It is a process that aids institutions in developing and sustaining effective educational programs and assures the educational community, the general public, and other organizations that the accredited institution has met high standards of quality and effectiveness.

Accreditation of the university programmes and subsequent standardization across the tertiary institutions nationwide by the N.U.C remain substantively superficial especially in the absence of a mechanism to ascertain or ensure that the prescribed programmes are implemented by competent and qualified personnel both in the administrative and academic sectors of the university, according to laid down criteria.

Institutional accreditation has to incorporate both internal self assessment and external judgments. While it is very necessary that there should be certain minimum standards agreed upon and which guide the operations of institutions of similar status nationwide, it is equally desirable that recognition is given to the internal peculiarities of each. (Commission on Colleges Southern Association of Colleges and School, 2001)

Therefore, the process of accreditation should provide a means of recognizing some levels of performance, quality and integrity which engenders confidence from the public and the broad educational community. A perceived belief is that accreditation is purported to provide quality assessment which is monitored by bodies assessing quality in post secondary education, including governmental agencies and professional associations. (Enser, 2002)

It is also believed that the process of accreditation is undertaken in order to evaluate an institution or programs against some (usually not clearly articulated) minimally acceptable standards which protect the institutions themselves, their students and the public.

\section{Brief History Of Fountain University}

Fountain University is owned by Nasrul-Lahi-Il-Fatih Society of Nigeria (NASFAT); a leading Islamic Society in Nigeria. Fountain University is committed to the total development of men and women imbued with high academic, Islamic moral and ethical values in an enabling environment, through appropriate teaching, research and service to humanity. It is a University established to be a pace-setting institution in terms of learning, character-building and service to humanity. 
The main objective is to provide competitive and resourceful graduates with high moral standards. The university provides high level of teaching and learning opportunity to all people irrespective of race, tribe, religion or political inclinations, which is being achieved through effective programs and services based on provision of adequate facilities as well as professionally qualified and competent staff. All programs offered presently have been granted accreditation status by the National Universities Commission (NUC).

\section{Objectives of Accreditation}

The objectives of accreditation in an institution is as follows

- To promote and foster good quality university education and training for the production of high quality skilled manpower and similar levels of business manpower for the society.

- To ensure uniformity of standards in all programs offered by universities and similar tertiary institutions in Nigeria.

- To certify to the Nigerian Community that the programs offered by an institution have satisfied the minimum educational requirements as lay down by the National Universities Commission (NUC).

- To provide counsel and assistance to the established and developing institutions and programs where necessary.

\section{Importance Of The Accreditation}

There is no doubt that the quality of higher education determines the quality of human resources of a Country. One of the major objectives of the university is to produce qualified, skilled and globally competent workforce for the labor market of business and industry, which is a critical factor to national growth and development. Since no nation can develop beyond the quality of its higher education. Recent developments such as increasing student enrolments; reduced state funding for public higher education; increasing number of private providers; internationalization cross border education have also influenced the purpose and functions of higher education (Hayward, 2006). The need for global competiveness is another recent development that has impacted higher education in Nigeria. National Universities Commission (NUC), which is the regulatory body established to oversee the administration and delivery of higher education in Nigeria ensures the orderly development of a well coordinated and productive university system that will guarantee quality and relevant education for national development and global competitiveness (NUC, 2009).

\section{Role Of The Library}

Accreditation is a once in a lifetime opportunity for advancement not only of the physical plant and collection but also the career and economic status of the library staff. The library played a stirring role in the accreditation process of an institution. Academic libraries have successfully navigated a paradigm shift from information repositories to learning enterprises (Bennett, 2009) by embedding innovative library education, resources, and services in the teaching and learning activities of their institutions and designing facilities that increasingly engage students in learning.

Fountain University Library ensures the provision of facilities, services, and learning/information resources that are appropriate to support teaching, research, and service mission of the institution. Also, the library ensures that users have access to regular and timely instruction in the use of the library and other learning/information resources.

The Library provides a sufficient number of qualified staff-with appropriate education and experiences in library and other learning/ information resources- to accomplish the mission of the institution. Provision of adequate library materials to support the nature, level and scope of the different programs offered by the institution was also put in place. The library also maintained adequate and well organized collections which are accessible to all students, faculty, administrative and research staff.

Actions were taken in compliance to team of accreditation recommendations with emphasis on planning, outcomes of previous evaluation, utilization of information resources, involvement and collaboration of faculty and students in collection building.

Books, Journals and other electronic resources were acquired to build up collections in every program offered in the institution. The library did not only focus on input measures such as strengths and weaknesses of book collection but other information resources and services such as staffing, library hours, technical services, public services, allocation of resources and other aspects of library operations were also well taken care of. Librarians were actively involved in the accreditation because the provision and use of library materials and services affects the quality of the students' educational experience.

The way the university library manages and support library resources reflects the priorities of the institution, the educational goals and methods of faculty, and the performance of students and graduates. The future of accreditation practice is also of interest, since the standards that are established and enforced may 
affect the proportion of the institutional resources that are available to libraries and the expectations for their performance.

Furthermore, the current approach to accreditation emphasizes self-assessment and continuous improvement, providing useful management tools for librarians. Librarians understand how their participation in these processes can result in improvement for the library. In addition to their participation in the self-study of the parent institution, both the library and the institution benefit.

\section{The Process Of Accreditation}

The process for initial and continued accreditation involves a collective analysis and judgment by an institution's internal constituencies, an informed review by peers external to the institution, and a reasoned decision by the members of the Commission on the institution. Fountain University periodically conduct internal reviews involving the administrative officers, staff, faculties, library, students, trustees, and others appropriate to the process. The internal review allows the institution to consider its effectiveness in achieving its stated mission and its compliance with the accreditation requirements established by the National Universities Commission (NUC).

Furthermore, accreditation helps the institution to evaluate its efforts in enhancing the quality of student learning and the quality of programs and services offered, as well as challenging itself to examine its successes in accomplishing its mission. At the culmination of the internal review, peer evaluators representing the Commission apply their professional judgment through a preliminary assessment of the institution; to make the final determination of the institution's compliance with the accreditation requirements.

\section{Steps of the Accreditation Process}

The following list discusses each step taken during the accreditation process:

\section{Preparation and self-examination:}

The University prepares materials that effectively display the institution's accomplishments. The institution also creates a written report of its accomplishments according to the standards set by the NUC.

\section{Peer review:}

Administrative and faculty peers conducted an intensive review of the prepared materials, written report, and the general workings of the university. Teams of peer reviewers visited the institution.

\section{Visit and examination:}

In addition to the visits made by the peer reviewers, a visiting team was also gathered to visit the university. This team was made up of peers and members of the govern council of the university, the parent organization; Nasrullahi-il-fatih society (NASFAT), stakeholders who volunteered their time because of the strong interest in the quality standards of higher education institutions.

\section{Judgment action made by accreditation organization:}

After the previous steps were completed, the university calls upon the commission to review the steps and affirm the accreditation status of the university.

\section{Continuous review:}

By accepting accreditation status, the university, agrees to undergo a review on a rotating basis every few years or sometimes every ten years. An institution is usually required to go through all the steps of the accreditation process each time it is reviewed. The purpose of the continuous review is to ensure that the accredited institution continues to maintain the required accreditation standards.

\section{Conclusion}

After the accreditation exercise, Fountain University was granted accreditation for the entire course offered presently. However, the accreditation exercise brings about the full understanding of the relationship between the institution mission and the diversity of society. The institution's educational responsibilities take primacy over other purposes, such as generating financial returns for investors, contributing to the parent organization, or supporting external interests. The institution operates with integrity in its financial, academic, personnel, and auxiliary functions; it establishes and follows fair and ethical policies and processes for its governing board, administration, faculty, and staff.

Fountain University presents itself clearly and completely to its students and to the public with regard to its programs, requirements, faculty and staff, costs to students, control, and accreditation relationships. The 
governing board of the institution is sufficiently autonomous to make decisions in the best interest of the institution and to assure its integrity. The university reviews and considers the reasonable and relevant interests of the institution's internal and external constituencies during its decision-making deliberations. The university preserves its independence from undue influence on the part of donors, elected officials, ownership interests, or other external parties when such influence would not be in the best interest of the institution.

Fountain University is committed to freedom of expression and the pursuit of truth in teaching and learning. The institution ensures that faculty, students, and staff acquire, discover, and apply knowledge responsibly. The institution provides effective oversight and support services to ensure the integrity of research and scholarly practice conducted by its faculty, staff, and students. Students are offered guidance in the ethical use of information resources. The institution has and enforces policies on academic honesty and integrity.

Courses and programs are current and require levels of performance by students appropriate to the degree or certificate awarded. The institution articulates and differentiates learning goals for its undergraduate, graduate, and post-graduate programs. The institution demonstrates that the exercise of intellectual inquiry and the acquisition, application, and integration of broad learning and skills are integral to its educational programs. The institution has sufficient numbers and continuity of faculty members to carry out both the classroom and the non-classroom roles of faculty, including oversight of the curriculum and expectations for student performance; establishment of academic credentials for instructional staff; involvement in assessment of student learning.

Instructors are evaluated regularly in accordance with established institutional policies and procedures. The institution has processes and resources for assuring that instructors are current in their disciplines and adept in their teaching roles; it supports their professional development. Instructors are accessible for student inquiry. Staff members providing student support services, such as tutoring, financial aid advising, academic advising, and co-curricular activities, are appropriately qualified, trained, and supported in their professional development.

The institution provides to students, guidance in the effective use of research and information resources. The institution fulfills the claims it makes for an enriched educational environment. The institution demonstrates any claims it makes about contributions to its students' educational experience by virtue of aspects of its mission, such as research, community engagement, service learning, religious or spiritual purpose, and economic development. The institution demonstrates responsibility for the quality of its educational programs, learning environments, and support services, and it evaluates their effectiveness for student learning through processes designed to promote continuous improvement.

Finally, Fountain university learns from its operational experience and applies that learning to improve its institutional effectiveness, capabilities, and sustainability, overall and in its component parts.

\section{References}

[1]. Bennett, S. (2009). Libraries And Learning: A History Of Paradigm Change. Libraries And The Academy, 9(2), $181-197$.

[2]. Commission On Colleges Southern Association Of Colleges And School (2001) Principles Of Accreditation: Foundations For Quality Enhancement.44p.

[3]. Dalrymple.W. Prudence (2001) Understanding Accreditation: The Librarians Role In Educational Evaluation. Libraries And The Academy, 1(1), 23-32.

[4]. Enser .P. (2002) The Role Of Professional Body Accreditation In Library And Information Science Education In The UK. Libri, Vol $52(1), 214-219$.

[5]. Stamatoplos, A. (2009) The Role Of Academic Libraries In Mentored Undergraduate Research: A Model Of Engagement In The Academic Community.

[6]. Corazon, M.N. (2003). The Impact Of Accreditation To Libraries And Librarianship: The Philippine Experience.

[7]. http://www.fountainuniversity.edu.ng 